\title{
TESTING LENIENCY PROGRAMS EXPERIMENTALLY: THE IMPACT OF CHANGE IN PARAMETERIZATION
}

\section{Jana Krajčová}
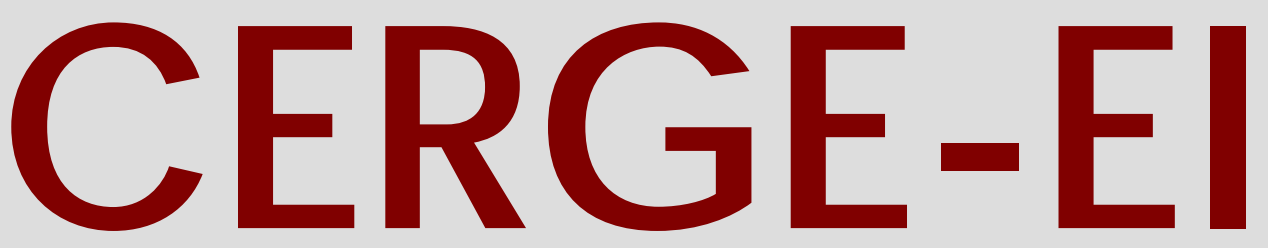

Charles University Centerfor Ec onomic Research and Graduate Education Academy of Sciences of the Czech Republic Ec onomic s Institute 


\title{
Working Paper Series $\quad 370$ (ISSN 1211-3298)
}

\section{Testing Leniency Programs Experimentally: The Impact of Change in Parameterization}

\author{
Jana Krajčová
}

CERGE-EI

Prague, October 2008 
ISBN 978-80-7343-170-9 (Univerzita Karlova. Centrum pro ekonomický výzkum a doktorské studium)

ISBN 978-80-7344-159-3 (Národohospodářský ústav AV ČR, v.v.i.) 


\title{
Testing Leniency Programs Experimentally: The Impact of Change in Parameterization*
}

\author{
Jana Krajčová ${ }^{\dagger}$ \\ CERGE-EI $I^{\ddagger}$
}

October 2008

\begin{abstract}
I analyze subjects' sensitivity to parametric change that does not affect the theoretical prediction. I find that increasing the value of an illegal transaction to a briber and reducing the penalties to both culprits leads to more bribes being paid but does not affect the cooperation of the bribee. My data also suggest that trust and preferences towards others might play a role. My paper provides a testbed for experimental testing of anti-corruption measures and adds evidence to the on-going discussion on the need for sociodemographic controls.
\end{abstract}

\begin{abstract}
Abstrakt
Analyzujem dopad zmeny parametrov, ktorá neovplyvňuje teoretickú predikciu, na rozhodovanie účastníkov experimentu. Zistila som, že zvýšenie výplaty plynúcej platcovi úplatku z ilegálnej transakcie a súčastné zníženie penále pre oboch páchatel'ov vedie k zvýšeniu korupcie, avšak nemá vplyv na d'alšie rozhodovanie príjmatel'a úplatku. Moje výsledky tiež naznačujú, že dôvera a preferencie voči blahu iných môžu zohrávat' dôležitú úlohu pri rozhodovaní. Môj článok poskytuje východiskový testovací základ pre experimentálne testovanie protikorupčných opatrení, a tiež prispieva k pokračujúcim diskusiám o význame sociodemografických charakteristík pri analýze experimentálnych dát.
\end{abstract}

Keywords: corruption, anti-corruption mechanisms, optimal contract, monitoring

JEL classification: C91, D02, D73, K42

${ }^{*}$ My special thanks go to Prof. Andreas Ortmann for consultation on and supervision of this research. I would also like to thank Ondřej Rydval, Peter Katuščák, Lenka Drnáková, and especially Libor Dušek for valuable tips and very helpful suggestions and comments. This study was supported by GAČR grant No. 402/04/0167.

${ }^{\dagger}$ E-mail: jana.krajcova@cerge-ei.cz

${ }^{\ddagger}$ Center for Economic Research and Graduate Education-Economics Institute, a joint workplace of Charles University in Prague and the Academy of Sciences of the Czech Republic. Address: CERGE-EI, P.O. Box 882, Politických věznnu 7, Prague 1, 111 21, Czech Republic. 


\section{Introduction}

The severe consequences of corruption have been documented in numerous empirical studies. For example, Mauro (1995) and Tanzi (1998) have shown a negative effect of corruption on economic growth; Hwang (2002) has demonstrated that corruption, through tax evasion, reduces government revenues; and Gupta, Davoodi and Alonso-Terme (2002) have shown that corruption increases income inequality and poverty. The design and implementation of effective anti-corruption measures therefore remains an important concern.

One promising anti-corruption measure is the leniency policy. Leniency policies award fine reductions of varying intensities to wrongdoers who "spontaneously" report an illegal agreement and thereby help to convict their accomplice(s). They serve as an enforcement mechanism as much as a means of deterrence in that, if appropriately designed and implemented, they have the potential to undermine the trust between wrongdoers. Leniency policies have been analyzed in the literature mostly as an anti-cartel mechanism.

The deterrence effect of leniency policies in the case of cartels has been analyzed - and confirmed - both theoretically (e.g. Spagnolo 2004) and experimentally (e.g. Apesteguia, Dufwenberg and Selten 2004; Bigoni, Fridolfsson, Le Coq and Spagnolo 2007, 2008).

Spagnolo (2004), for example, theoretically examines the effects of leniency policies of various degrees - from moderate (which reduce or cancel the penalty for a criminal who reports) to full (which, in addition, pay a reward). He shows that reward-paying leniency programs provide a (socially) $\operatorname{costless}^{1}$ and very efficient measure for cartel deterrence.

\footnotetext{
${ }^{1}$ This is the case if the rewards are fully financed from fines imposed on other convicted members of the cartel.
} 
Drawing on earlier versions of Spagnolo (2004), Apesteguia, Dufwenberg and Selten (2004) conducted an experiment that confirms the promising cartel-deterring properties of leniency policies. Bigoni, Fridolfsson, Le Coq and Spagnolo (2007, 2008) conducted related experiments. In addition to confirming the basic results about the effectiveness of leniency programs, they attempted to acquire a deeper understanding of the driving forces. In several treatments they vary specific features of the game - fine levels, exogenous risk of detection, reward schemes, possibility to communicate, and the eligibility for leniency. They control for past convictions and for subjects' risk attitudes. The experiments are run in Stockholm and in Rome, which allows assessing potential cultural effects.

Bigoni et al (2007) find that leniency leads to higher deterrence but at the same time helps to sustain higher prices. Rewards lead to almost complete deterrence which is in line with Spagnolo's (2004) result. Past convictions reduce the number of cartels but increase collusive prices. The authors, in addition, distinguish between two types of past convictions 1) those that occur as a result of reporting and 2) those that occur as a result of external investigation. They find that past convictions after reporting have a much stronger deterrence effect than past convictions after external investigation. The results also confirm a strong cultural effect.

Bigoni et al (2008) focuses on the role of risk attitudes. They find that risk aversion and the willingness to form a cartel are negatively correlated. The results suggest that past experience might have more important consequences for the perception of risk than the exogenous probability of detection, and that the strategic risk (the risk of being cheated upon) plays a key role for the effectiveness of a leniency policy.

Both Bigoni et al (2007) and (2008) contribute to a better understanding of the cartel-deterring properties of leniency policies and highlight the importance of proper policy design. 
Leniency policies to deter cartels are, however, not directly applicable as anticorruption measures, since cartel deterrence is essentially a simultaneous game while strategies, payoffs, and the move structure of anti-corruption measures are asymmetric. ${ }^{2}$ A proper theoretical and experimental analysis is therefore called for.

To my knowledge the first theoretical work analyzing the various effects of leniency policies on corruption is Buccirossi \& Spagnolo (2006). The authors show that poorly designed moderate policies may have a serious counter-productive effect: they might allow a briber to punish at relatively low cost a partner who does not respect an illegal agreement. In other words, some leniency policies might actually provide an enforcement mechanism for occasional illegal transactions. ${ }^{3}$ Thus they can, contrary to the intention, increase corruption.

Buccirossi \& Spagnolo's result together with the theoretical and experimental evidence from the literature on cartel deterrence suggests that the potential of leniency policies to undermine trust between wrongdoers hinges upon proper design and implementation.

Experimental methods have been widely used, albeit rarely, to study corruption (Dušek, Ortmann and Lízal 2005). They become especially useful when counterfactual institutional arrangements such as leniency programs need to be explored: they provide, for example, relatively cheap ways to examine the effects of such arrangements in controlled environments (see Dušek et al 2005, Apesteguia et al 2004, Buccirossi \& Spagnolo 2006, Bigoni et al 2007, 2008, Richmanová \& Ortmann 2008, and also Roth 2002).

In Richmanová \& Ortmann (2008) we proposed a generalization of the Buccirossi \& Spagnolo (2006) model by introducing the probabilistic discovery of evidence. ${ }^{4}$ Our generalization makes the model more realistic and more readily appli-

\footnotetext{
${ }^{2}$ For a more detailed discussion see Richmanová (2006).

${ }^{3}$ Occasional illegal transactions are essentially one-shot transactions.

${ }^{4}$ In the original model, Buccirossi \& Spagnolo assume that the briber and bribee agree to
} 
cable for experimental testing without changing the qualitative results of Buccirossi \& Spagnolo.

We use the generalized Buccirossi \& Spagnolo model for the experimental testing of leniency policies as an anti-corruption measure. As we address two different methodological issues that (anti-)corruption experiments are afflicted with, our results are reported in two papers: the present paper, and the closely related work reported in Krajčová \& Ortmann (2008). Both papers provide a new testbed for anti-corruption programs.

Altogether, we design three experimental treatments: a benchmark, which is common for both studies, Krajčová \& Ortmann (2008) and the present paper, and in which all instructions are presented in completely neutral language; a context treatment, in which we use the same parameterization as in the benchmark but instructions are presented in full bribery context (Krajčová \& Ortmann 2008); and a high-incentive treatment, which implements a new parameterization within neutral framing (the present paper). ${ }^{5}$

In Krajčová \& Ortmann (2008), following the earlier work of Abbink \& HennigSchmidt (2006), we study the effect of "loaded" instructions in a bribery experiment. Surprisingly, Abbink \& Hennig-Schmidt find no significant impact of instructions framing. The authors conclude that this result may be caused by the nature of the game: it is very simple, and as it was designed to capture all the basic features of bribery, even with neutral wording, subjects may have deciphered what the experiment was about. Our bribery game includes stages where players can report their opponents and receive leniency, which makes it more complex and also produce hard evidence, which serves as a hostage. Without hard evidence being produced, the occasional illegal transaction is not enforceable. An audit, if it takes place, discovers the evidence with a probability of one. In Richmanová \& Ortmann (2008), we argue that instead some evidence is created unintentionally and this can be discovered by an audit with some probability that is less than one.

${ }^{5}$ We have, in addition, designed some additional exploratory treatments which we use for a robustness check of the main results. See the appendix for more details. 
potentially more susceptible to the non-neutral context. Therefore, it calls for a separate analysis. We find a strong gender effect - male and female participants react differently to the non-neutral context. The effect of context becomes significant once we allow for gender-specific coefficients. Thus, in contrast to the results of Abbink \& Hennig-Schmidt (2006), we find that a bribery context indeed makes a (significant) difference.

In the present paper I study the effect of a change in parameterization. It has been documented in the literature that a change in parameterization that does not affect the theoretical prediction might indeed have consequences for the behavior of subjects in the lab (see e.g. Goeree \& Holt 2001). Anti-corruption experiments might be particularly tricky, being sensitive to changes in design. In the generalized Buccirossi \& Spagnolo game, the action bringing the highest possible payoff is also associated with a risk of considerable loss. Therefore, risk or loss attitudes are also likely to play a role. Altogether, I expect that subjects in the lab might not behave in accordance with the theoretical prediction, especially when the prediction is made under an assumption of risk neutrality. ${ }^{6}$ The question I ask is whether by making corruption more attractive by i) increasing the potential gain and ii) reducing the penalty if bribery is discovered, I can induce more corruption in the lab even if the theoretical prediction suggests no change. I also study to what extent the subjects' decisions in the experiment can be explained by their basic socio-demographic characteristics.

I do indeed find a significant effect of parametric change. Even though the change I implemented has no consequences for the theoretical prediction, I observe much more corruption in the high-incentive than in the benchmark treatment. My data suggest that trust and preferences towards others might play a role. The econometric analysis provides limited evidence on the role of basic socio-demographic

\footnotetext{
${ }^{6}$ In fact, in our data we observe deviations from the theoretical prediction in all three treatments.
} 
characteristics. I find no differences in how the parametric change affects the behavior of male and of female participants. Our papers provide a testbed for the experimental testing of anti-corruption measures and add evidence to the on-going discussion on the need for socio-demographic controls.

The remainder of the paper is organized as follows. In the next section I discuss the generalized Buccirossi \& Spagnolo model in detail, and I also describe and compare two experimental treatments. Section 3 talks about experimental implementation and in Section 4 I review the results. Section 5 concludes.

\section{Experimental Design}

The experiment implements the bribery game in Richmanová \& Ortmann (2008). An entrepreneur has an investment possibility of net present value $v$, if a bureaucrat is willing to perform an illegal action, Action a. For doing so, the bureaucrat may require compensation in the form of a bribe, $b$.

The timing of the game is as follows. First, the entrepreneur decides whether to Pay or Not Pay a bribe. If she does not pay a bribe, the game ends. If she does, the bureaucrat chooses one of three possible actions: Denounce, do Nothing, ${ }^{7}$ or perform Action ${ }^{8}{ }^{8}$

If the bureaucrat chooses Denounce, an audit is carried out. The audit may (with probability $\beta, \beta \in(0,1)$ ), or may not (with probability $1-\beta$ ), discover some evidence of bribery. If the bribery attempt is detected, the leniency policy

\footnotetext{
${ }^{7}$ Nothing denotes a passive action choice. For the bureaucrat, it means that he neither denounces nor respects (by providing the favor) the illegal agreement. For the entrepreneur, it means that she does not denounce in response to the bureaucrat's action.

${ }^{8}$ Action a means that the bureaucrat respects the illegal agreement and thus provides an (illegal) favor to the entrepreneur. That is, strictly speaking, not a corrupt action because it does not impose a negative externality on the public. According to Abbink, Irlenbusch \& Renner (2002) it is not such a problem since people do not care much about the costs they impose on others.
} 
guarantees that the bureaucrat will have to pay only a reduced fine whereas the entrepreneur will have to pay the full fine. In addition, bribe $b$ is confiscated. ${ }^{9}$ If the bribery is not detected, the bureaucrat will enjoy bribe $b$.

If the bureaucrat chooses Nothing or Action a, the entrepreneur has another move. In both cases, she may choose between Denounce and do Nothing.

If the entrepreneur chooses Denounce and the ensuing audit discovers evidence (which, again, happens with probability $\beta$ ), then she will have to pay a reduced fine whereas the bureaucrat will have to pay the full fine and, in addition, their illegal gains will be confiscated. If no evidence is discovered, both the bureaucrat and the entrepreneur will keep their illegal gains.

If the entrepreneur chooses Nothing, then an audit may still occur with some nonzero probability $\alpha$. If the audit detects bribery (which happens with probability $\beta$ ), both parties are subject to a sanction, which consists of the confiscation of the illegal gains plus the full fine. The illegal gains include bribe $b$ in any case and value $v$ only in the case when the bureaucrat has chosen to perform Action a.

Figure 1 below summarizes the extensive form of the game and the expected payoffs.

The contribution of the generalized model lies in the introduction of probability $\beta$. In Buccirossi \& Spagnolo (2006) it is assumed that, before the illegal transaction takes place, the bureaucrat and the entrepreneur agree on the production of hard evidence. Without hard evidence being voluntarily produced by both of them the illegal transaction is not enforceable. In essence it is assumed that both involved are holding a hostage that commits each other to the desired outcome. It is furthermore assumed that, if an audit takes place, corruption is discovered and both culprits are convicted with a probability of one. Richmanová \& Ortmann (2008) assume

\footnotetext{
${ }^{9}$ Note that in this case the illegal transaction has been detected without Action a being performed and therefore there is no gain to the entrepreneur to be confiscated.
} 


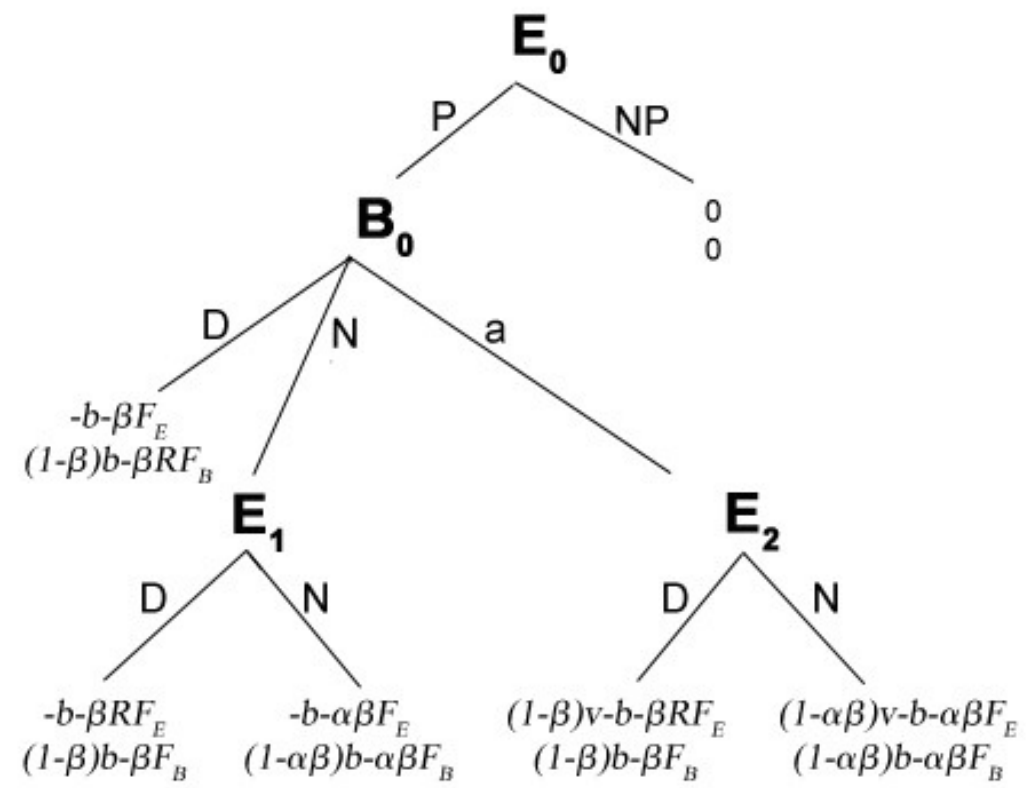

Figure 1: Extensive form of the corruption game in the generalized model. $P$ stands for Pay, $N P$ for Not Pay, $D$ for Denounce, $N$ for doing Nothing, $a$ for performing Action $a, b$ for bribe, $v$ for the value of the project to the entrepreneur, $\alpha$ for the exogenous probability of an audit, $\beta$ for the probability of conviction, $F_{E}$ and $F_{B}$ for full fines and $R F_{E}$ and $R F_{B}$ for reduced fines to the entrepreneur and to the bureaucrat, respectively.

instead that some hard evidence is created unintentionally along the way and that this evidence may be discovered by an audit with probability $\beta \in(0,1)$. The basic structure of both the original and the modified game is the same except that in the original version the probability $\beta$ is set to 1 . The generalization makes the model more suitable for experimental testing, as no additional stage is needed in which subjects would have to agree on producing a hostage. In addition, the generalized model arguably resembles real-world situations more closely. ${ }^{10}$

Buccirossi \& Spagnolo (2006) show that in the absence of a leniency program, occasional illegal transactions are not implementable. ${ }^{11}$ The result carries over into

\footnotetext{
${ }^{10}$ I realize that in such a game beliefs about the probability of detection might play an important role. However, I believe that the introduction of beliefs would make the game more complex than necessary for experimental testing. Instead, I view probability $\beta$ as an empirical success rate, or effectiveness, of a detection technology that is known to subjects.

${ }^{11}$ Facing the full fine even after reporting, the entrepreneur cannot credibly threaten to report the bureaucrat in the case when he would not deliver. Therefore, the bureaucrat would keep the bribe and not perform Action a, knowing that it is not profitable for the entrepreneur to punish him. Consequently, the entrepreneur would not enter the illegal agreement in the first place.
} 
the generalized model. After the introduction of a modest leniency program, ${ }^{12}$ occasional illegal transactions are enforceable if the following three conditions are satisfied simultaneously. First, the no-reporting condition for the bureaucrat: the reduced fine must be such that the bureaucrat prefers performing Action a to Denouncing once the bribe has been paid. Second, the credible-threat condition for the entrepreneur: the reduced fine and the full fine must be set such that the entrepreneur can credibly threaten to report if the bureaucrat does not deliver. Third, the credible-promise condition: the entrepreneur must be able to credibly promise not to report if the bureaucrat respects the illegal agreement.

These three conditions, given the value of the project together with the full and reduced fines, define a bribe range for which the occasional illegal transaction is implementable. Even though these conditions are modified in the generalized model, the qualitative result remains unaffected.

I used the generalized version of the game for experimental testing of the theoretical prediction under two different scenarios: when the occasional illegal transaction is implementable in equilibrium, and when it is not. Implementability is a function of the per-round endowment for the entrepreneur. The per-round endowment exogenously defines the value of the bribe if the entrepreneur decides to pay it. ${ }^{13}$ For each treatment I use two possible values of the per-round endowment: a low endowment that theoretically leads to a no-corruption equilibrium, and a high endowment that theoretically leads to a corruption equilibrium.

I want to study whether a change in parameterization that does not affect the theoretical prediction will have an impact on the behavior of subjects in a lab. In a game like this, where an action bringing the highest possible payoff is also

\footnotetext{
${ }^{12}$ Similarly to Spagnolo (2004), "modest" means that a leniency program does not reward for reporting, at best it cancels the fine.

${ }^{13}$ This way I reduce the cognitive demand on subjects: the only decision they have to make is whether they want to transfer their per-round endowment or not.
} 
associated with the risk of an enormous loss, it is likely that subjects in the lab will not behave in full accordance with the theoretical prediction. I want to see whether by making the risky choice more tempting I can induce more transferring in the lab. I also want to see what the consequences are for later stages of the game, particularly for denouncing. For that purpose I ran two treatments: a benchmark and a high-incentive treatment.

Table 1 below summarizes the parameterizations chosen for the Benchmark treatment $(B)$ and for the ( Benchmark-) High-incentives treatment $(B H)$.

\begin{tabular}{|l|l|l|l|l|l|l|l|l|l|l|}
\hline Treatment & $\alpha$ & $\mathrm{b}$ & $\mathrm{v}$ & $\mathrm{RF}_{E}$ & $\mathrm{RF}_{B}$ & $\mathrm{~F}_{E}$ & $\mathrm{~F}_{B}$ & $\mathrm{E}_{L}$ & $\mathrm{E}_{H}$ & show-up \\
\hline B & 0.1 & 0.2 & 100 & 0 & 0 & 300 & 300 & 20 & 40 & 300 \\
\hline BH & 0.1 & 0.2 & 200 & 0 & 0 & 200 & 200 & 10 & 30 & 200 \\
\hline
\end{tabular}

Table 1: Experimental parameterization. $\alpha$ and $\beta$ denote the probability of an audit and of discovering evidence of bribery, respectively; $v$ denotes the value of the project to the entrepreneur; $R F_{E}$ and $R F_{B}$ denote reduced fines and $F_{E}$ and $F_{B}$ full fines to the entrepreneur and to the bureaucrat, respectively; $E_{L}$ and $E_{H}$ denote low and high per-round endowment, respectively; show-up stands for the show-up fee.

In the $\mathrm{B}$ treatment, the probabilities $\alpha$ and $\beta$ were chosen such that they approximately correspond to real-world exogenous probabilities of audit and to real-world conviction rates; at the same time they are intuitively comprehensible for subjects. The value of the project $v$ was chosen together with full fines $F_{E}$ and $F_{B}$ such that the subject faces a considerable gain from the investment but also severe punishment in the case of detection. I set reduced fines $R F_{E}$ and $R F_{B}$ equal to zero to analyze the case of full leniency programs which, according to Apesteguia et al (2004), have promising anti-cartel properties. Endowment determines the value of a bribe to (not) be paid. The "low endowment" of 20 leads (theoretically) to no corruption, whereas the "high endowment" of 40 leads to corruption equilibrium. Finally, the show-up fee was set such that I eliminate the possibility of earning a negative total from the experiment.

In the $\mathrm{BH}$ treatment, in order to make the risky but high-payoff choice more 
tempting, I increased the value of the project to the entrepreneur and, at the same time, I reduced the fines both agents face in case of detection. I keep the probabilities of detection and of conviction (thus the exogenous risk) unchanged. In order to keep the theoretical prediction for low- and high-endowment periods qualitatively the same as in the benchmark treatment, the per-round endowments were also adjusted. Finally, the show-up fee is set such that subjects cannot end up with a negative final payoff, but there is a chance that they will earn zero.

The extended game forms together with the expected payoffs resulting from the parameterizations for both the $B$ and the $B H$ treatments are illustrated in Figure 2 for low- and for high-endowment periods. The branches identifying the equilibrium choices of risk-neutral agents are in bold.

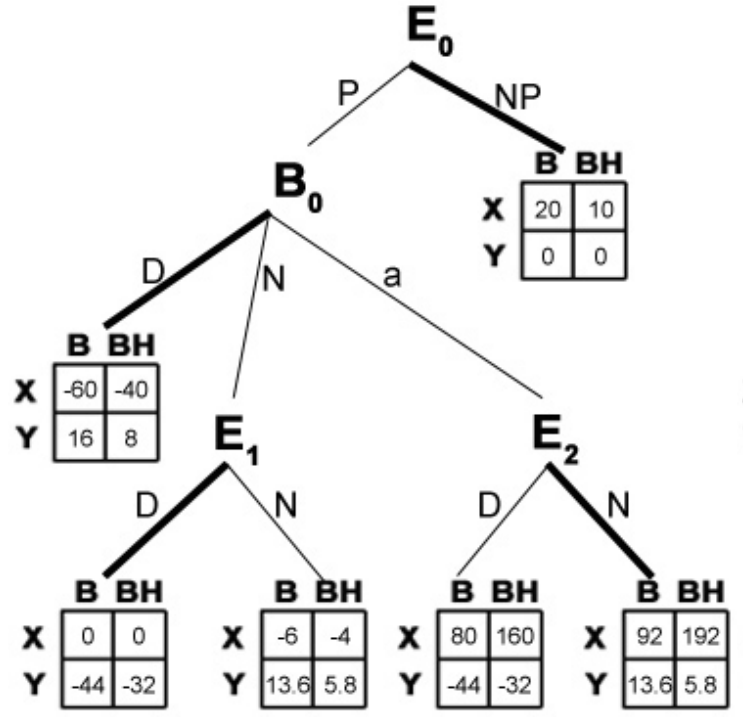

Low-endowment periods

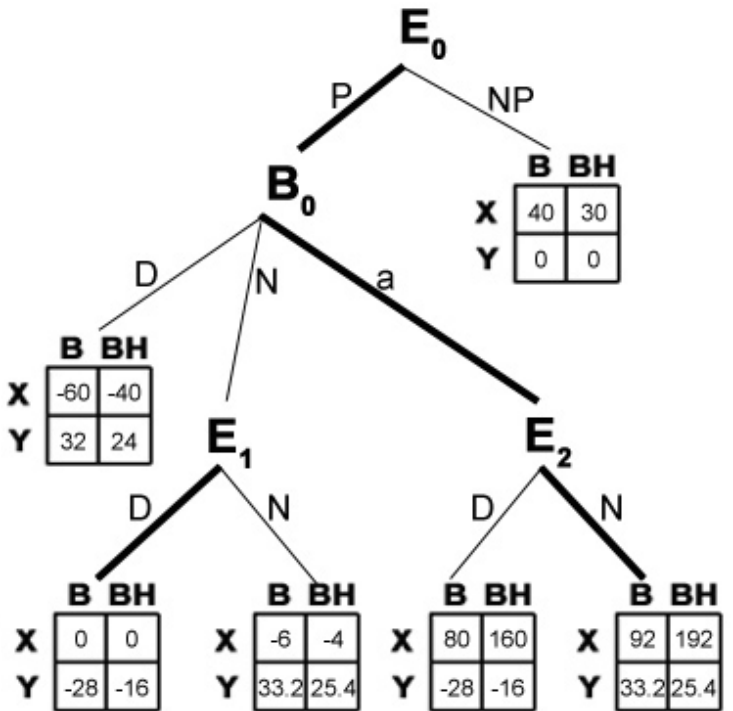

High-endowment periods

Figure 2: Expected payoffs from the corruption game in the B (benchmark) and the BH (highincentive) treatments, respectively. Rows in the tables correspond to Participant $\mathrm{X}$ and Participant $\mathrm{Y}$; columns correspond to the $\mathrm{B}$ and $\mathrm{BH}$ treatments. The theoretical prediction is the same for both treatments, it only varies with the endowment. 


\section{Implementation}

The experiment was conducted in November and December 2006 at CERGE-EI in Prague, using a mobile experimental laboratory. ${ }^{14}$

Participants were recruited from the Faculty of Social Sciences of Charles University in Prague and from various faculties of the Czech Technical University in Prague. Students were approached via posters distributed on campus and via email. ${ }^{15}$

I conducted four sessions of each treatment. Twelve participants, six in a role of Participant $\mathrm{X}$ - the entrepreneur - and six in a role of Participant $\mathrm{Y}$ - the bureaucrat - interacted in each session. In each session, all subjects participated in six rounds during which they kept the role that was assigned to them at the beginning of the first round. ${ }^{16}$ Participants were randomly and anonymously rematched after each round so that no subject was matched twice with the same coplayer. This was common knowledge. The incentive compatibility of this matching scheme is discussed in Kamecke (1997).

Table 2 summarizes the demographic characteristics of subjects participating in the experiment. The majority of my subjects were male, reflecting the composition of the subject pools that I drew on. Mean age ranges between 20.9 and 22.9, over all sessions the minimum is 18 and maximum 27. I also measured subjects' risk

\footnotetext{
${ }^{14} \mathrm{http}: / /$ home.cerge-ei.cz/ortmann/BA-PEL.htm

${ }^{15}$ By email, I also directly invited students who participated earlier in unrelated experiments conducted at CERGE-EI.

${ }^{16}$ After each Participant $\mathrm{X}$ interacted exactly once with each Participant $\mathrm{Y}$, the roles were switched for another six rounds. Subjects were not informed about the switch of roles in advance in order to avoid a possible impact on their behavior in the first six rounds. Before the beginning of the seventh round the announcement about the switch of roles appeared on their screens. The decisions in the last six rounds are likely affected by subjects' experience from the first six rounds and therefore I do not report them in the main text. A comparison of the before-switch and after-switch data is provided in the appendix. For the B treatment, I observe more transferring in the after-switch data, and also more denouncing in both the second and the third stage. In the BH treatment, I observe less denouncing in the second stage. The rest of the results seems unaffected.
} 
aversion using a questionnaire based on Holt \& Laury (2002). Mean RA score ranged between 24.8 and 34.7, over all sessions the minimum is 15 and maximum 51. ${ }^{17}$ Average final payoffs for the B treatment ranged from 320 to 330, with the minimum being 300 and the maximum 400; for the $\mathrm{BH}$ treatment it ranged between 185.8 and 309.2 , with the minimum being $0^{18}$ and the maximum $400 .{ }^{19}$

\begin{tabular}{|l|l|l|l|l|l|l|}
\hline Treatment & $\begin{array}{l}\text { Subject } \\
\text { Source }^{20}\end{array}$ & $\begin{array}{l}\text { M/F } \\
\text { ratio }^{21}\end{array}$ & $\begin{array}{l}\text { mean } \\
\text { (age) }\end{array}$ & $\begin{array}{l}\text { mean } \\
\text { (RA score) }\end{array}$ & $\begin{array}{l}\text { mean } \\
\text { (final pay) }^{22}\end{array}$ & Irreg $^{23}$ \\
\hline B & FSS & $8 / 4$ & 20.9 & 29.7 & 320 & 1 \\
\hline B & FSS & $10 / 2$ & 21.75 & 28.8 & 330 & 0 \\
\hline B & CTU & $11 / 1$ & 22.9 & 34.7 & 330 & 0 \\
\hline B & FSS & $9 / 3$ & 22.3 & 26.4 & 323.3 & 0 \\
\hline BH & CTU & $9 / 3$ & 22.6 & 33 & 185.8 & 1 \\
\hline BH & CTU & $10 / 2$ & 22.8 & 28.9 & 309.2 & 0 \\
\hline BH & CTU & $10 / 2$ & 22.5 & 29.3 & 241.7 & 1 \\
\hline BH & FSS & $10 / 2$ & 21.9 & 24.8 & 259.2 & 1 \\
\hline
\end{tabular}

Table 2: Summary of the demographic characteristics of subjects for all eight sessions.

Each session began with general instructions. Afterwards, subjects were asked to fill in Risk-aversion and Demographic questionnaires, for which they earned their show-up fee. Then the instructions to the computerized part of the experiment were distributed. Understanding of the instructions was tested by a brief

\footnotetext{
${ }^{17}$ The higher the score the more risk averse the subject is. The maximum possible RA score is 60 which, using the standard CRRA utility function $x^{(1-r)}$, approximately corresponds to a relative risk aversion coefficient of .17 . The minimum possible RA score is 0 , which approximately corresponds to a relative risk aversion coefficient of -.13. An RA score of 23 corresponds to riskneutrality.

${ }^{18}$ At that point $400 \mathrm{CZK}$ corresponded to about $16 \mathrm{USD}$, in purchasing power up to twice as much. Subjects were informed during recruitment that their final payoff from the experiment might be zero, but could not be negative. The non-negativity of the final payoff was ensured by the show-up fee.

${ }^{19}$ The difference in average payoffs in the $\mathrm{B}$ and in the $\mathrm{BH}$ treatment results from different parameterization as well as from different behavior of subjects as will be illustrated later.

${ }^{20}$ For each session, subjects were recruited from one source. FSS stands for the Faculty of Social Sciences in Prague, CTU for the Czech Technical University in Prague. I control for imbalance of the subject pool by including the econ and gender dummies in the econometric analysis.

${ }^{21}$ Male/Female ratio in the session.

${ }^{22}$ This is the average final payoff after the computerized part of the experiment.

${ }^{23}$ Irreg stands for a dummy variable for session irregularities. In the first B-treatment session an experimenter effect is possible; in the first BH-treatment session a typo in the Z-tree program caused incorrect payoffs for two final nodes displayed on the screens, which was pointed out by one of the subjects only after several rounds; in the third BH-treatment session two subjects continued communicating despite several admonitions; and in the fourth BH-treatment session two subjects were reading a newspaper in between making their choices. I do not believe that these would matter but wanted to control nevertheless. After running the preliminary regressions I concluded that they indeed did not matter.
} 
questionnaire. The computerized part of the experiment started only after every participant answered all testing questions correctly. ${ }^{24}$ The session concluded with a final questionnaire asking for the subject's feedback on the experiment. ${ }^{25}$

All instructions were read aloud by the experimenter. As a part of the instructions subjects received a pictorial representation of the game with a minimum use of game-theoretic terminology. Probabilistic outcomes were presented in both probabilistic terms and frequency representation (see e.g. Gigerenzer \& Hoffrage 1995, or Hertwig \& Ortmann 2004). All instructions were presented in completely neutral language, with no reference to bribery. The roles of the bureaucrat and the entrepreneur were renamed Participant $X$ and Participant $Y$, actions were labelled with neutral letters, Pay/Not Pay a bribe was replaced with transfer/not transfer; and no detection/detection were labelled outcome $A$ and outcome $B$, respectively (for an analysis of the impact of loaded instructions see e.g. Abbink 2006 or Krajčová \& Ortmann 2008). ${ }^{26}$

The experiment was computerized using Z-tree software (Fischbacher 2007). At the beginning of each round, each participant was notified of her/his role. Participants X also learned their current per-round endowment. Then each pair interacted sequentially. ${ }^{27}$ Between the second and the third stage, Participants X were asked about their choices in each node of the third stage if they were to reach it. After they made their conditional choices, they learned the actual decision of their coplayer and they were asked to confirm, or to change, their previous choice. This mechanism allowed me to collect some additional data in rounds when the third stage was not reached.

\footnotetext{
${ }^{24}$ This was common knowledge.

${ }^{25}$ For filling out this last questionnaire, subjects were paid an additional 50-200 CZK (corresponds to about 2-9 USD) - the amount varied between sessions. This mechanism was used to adjust average earnings for the session to the level promised during the recruitment.

${ }^{26}$ Originals (in Czech) of all materials that subjects received during the experiment are available at http://home.cerge-ei.cz/richmanova/WorkInProgress.html.

${ }^{27}$ Choices were made by clicking the respective buttons on the screen. Subjects were notified that once they make their choice it would not be possible to take it back.
} 
At the end of each round subjects were given feedback about their action(s), the action(s) of the player they were paired with, the realization of the random outcome (A or B) and their resulting payoff. At the end, one round was randomly chosen to determine the final payoff from the computerized part of the experiment. This mechanism was chosen in order to ensure that the decision in every round is made as if in a one-shot game. This payment procedure was common knowledge ex ante.

Participants were paid anonymously in cash right after each session. I used the Czech crown as the currency unit throughout the whole experiment.

\section{Results}

In Figure 3 below, the results from low- and high-endowment periods are presented. Each figure integrates the results from both treatments - the B treatment data in the upper rows, the $\mathrm{BH}$ treatment below. The equilibrium choices for each case are in bold face.

For the aggregate first-stage data, a clear treatment effect can be observed the frequencies of choosing Pay are higher in the $\mathrm{BH}$ treatment than in the $\mathrm{B}$ treatment. In both treatments, the frequencies of choosing Pay are higher in the low-endowment periods than in the high-endowment periods, which contradicts the theoretical prediction. Intuitively, subjects seem to be willing to transfer their endowment in order to get a chance of receiving a high payoff, but they are more willing to put at stake a low endowment than a high. Instead of risking the high endowment they seem to prefer choosing the sure outcome.

As for the second-stage data, only relative percentages can be compared across treatments, as different numbers of subjects actually entered this stage of the game. In both low- and high-endowment periods, the results for the two treatments are 


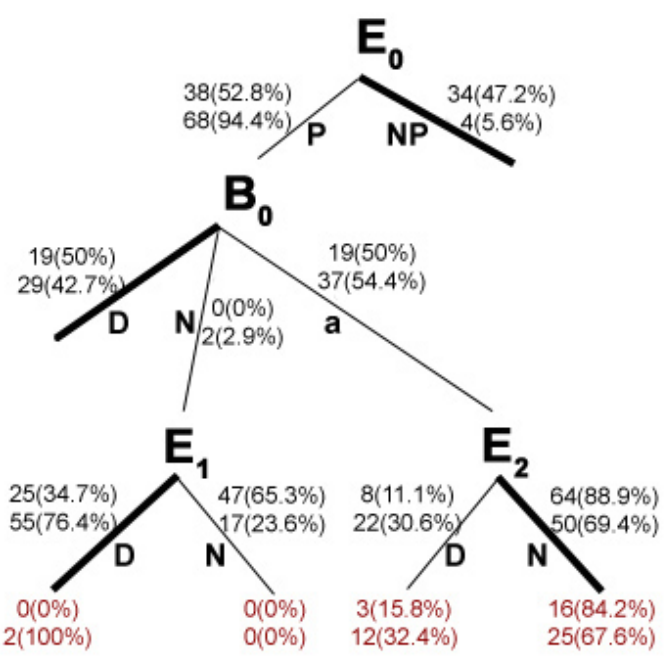

Low-endowment periods

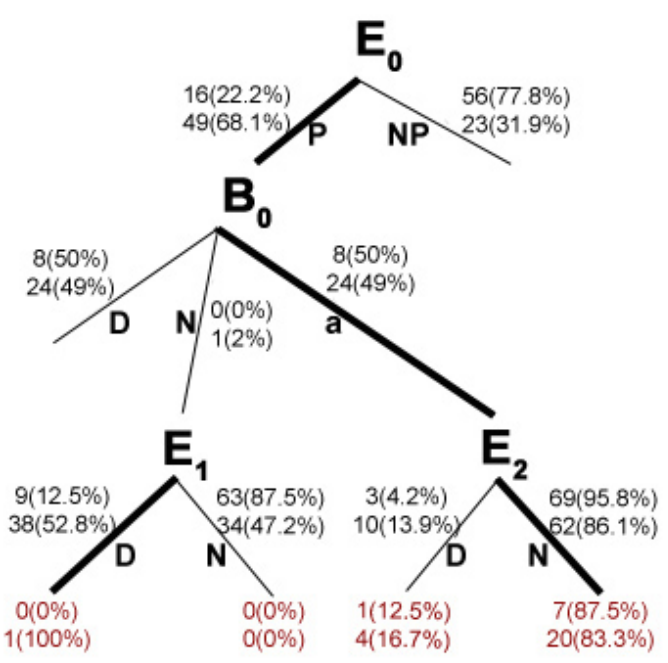

High-endowment periods

Figure 3: Experimental results. For each branch of the extensive form of the game, the upper row always displays the frequency of the action in the B treatment; and the lower row displays the frequency of the action in the $\mathrm{BH}$ treatment (both with the corresponding percentage in parentheses). For the nodes $E_{1}$ and $E_{2}$, above the branches, I present the conditional choices subjects were asked to report before they made their actual choice. Frequencies of real choices, which depend on the preceding decision of Participant $\mathrm{Y}$, are presented at the bottom part of each figure.

very similar: it is about an equal split between playing Denounce or Action a. Only in low-endowment periods of the $\mathrm{BH}$ treatment Action a slightly dominates. These results are not in line with the theoretical prediction. The difference in expected payoffs resulting from Denounce and Action $a$ is, however, very small and that may be the reason why I do not observe a stronger inclination to either choice. Also note that in both treatments Denounce is the only action through which the bureaucrat can avoid a negative expected round payoff with certainty. ${ }^{28}$ In line with theoretical prediction and also intuition, Nothing was almost never chosen.

As for the third-stage data, conditional choices provide mixed evidence. In the $E_{1}$ node, both conditional and sequential choices in the $\mathrm{BH}$ treatment are closer to the theoretical prediction than in the B treatment. In the $E_{2}$ node, it is just

\footnotetext{
${ }^{28}$ See Figure 2 and Table 1 for more details. Even though the subject could possibly earn a negative round payoff, each subject also received a show-up fee that ensured a non-negative total payoff.
} 


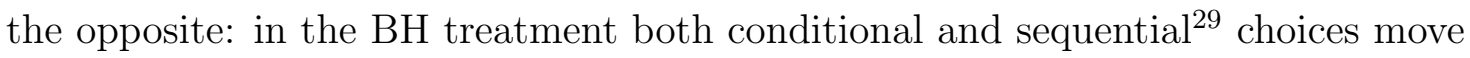
further away from the theoretical prediction.

Note that for the second and third stage data I have too few independent observations (especially so for the B treatment and for the high-endowment periods) ${ }^{30}$ to perform a reliable formal analysis. Therefore, I only perform statistical and regression analysis of the first-stage data.

\section{Analysis of the first-stage data}

In the following two subsections I report the results from the formal analysis of the first-stage data. I conducted standard non-parametric tests identifying differences in the distribution of choices under the two treatments. I also computed the effect size indices to measure the magnitude of the treatment effect. Finally, I report the results from the estimation of a linear probability model in which I control for some demographic characteristics of subjects.

Due to the panel nature of the data, I considered four different approaches to formal regression analysis: 1) clustered data analysis - data from periods 1,3 , and 5 (low-endowment) and from periods 2, 4, and 6 (high-endowment) are clustered by subject to correct standard errors for likely within-subject correlation; 2) firstperiod data analysis - only first-period data (for the low-endowment case) and only second-period data (for the high-endowment case) are analyzed; 3) averaged data analysis - averaged data for periods 1,3, and 5 and for periods 2, 4, and 6 are analyzed; and 4) dominant-choice data analysis - for each endowment value (low or high) each subject makes choices in three periods, and the dominant choice is

\footnotetext{
${ }^{29}$ When I asked subjects to make their real sequential choices, only one subject in the B treatment changed her/his decision in the $E_{2}$ node from Denounce to Nothing (after observing what Player 2 had chosen) in the low-endowment period. No one changed her/his decision in the high-endowment period or in the BH treatment.

${ }^{30}$ Recall that Figure 3 presents the aggregated data from all the relevant periods, therefore it contains repeated observations for individual subjects
} 
the one that is played more often.

Clustered data have the advantage of using all the available information, while the other three approaches use only a part of the available information. Therefore, in the main text I discuss the results for clustered data. The analysis of averaged, first-period, and dominant-choice data can be found in Appendix 2, part A, as a robustness check of the main results. By and large, there are no major findings in these robustness tests.

In addition to the robustness checks based on different "data handling" I also run a few additional exploratory sessions of treatments in which the experimental conditions are only slightly modified compared to the benchmark and the highincentive treatments. The results from the analysis on the extended data set is provided in Appendix 2, part B, as an additional robustness check of the main results. By and large, there are no major findings in these robustness checks. Pooling slightly different treatments leads to noisier results, which is not very surprising.

\subsubsection{Statistical analysis}

In Table 3 below I report the results of three standard non-parametric tests in order to identify the differences in the distributions of choices under the two treatments. Specifically, I test the null hypothesis of no differences between the two treatments using the averages of the binary transfer variable ${ }^{31}$ over periods 1,3 , and 5 and 2,4 , and 6. According to Wilcoxon rank-sum, Kolmogorov-Smirnov and Fisher's exact tests I reject the hypothesis of no differences in the distribution of choices under two treatments at the $5 \%$ significance level.

\footnotetext{
${ }^{31}$ Transfer has a value of one if Participant $\mathrm{X}$ chooses Pay and a value of zero if s/he chooses Not Pay in the respective period.
} 


\begin{tabular}{|l|l|l|l|}
\hline periods & Ranksum $^{32}$ & Ksmirnov $^{33}$ & Fisher $^{34}$ \\
\hline $1,3,5$ & -3.632 & .500 & $(.001)$ \\
& $(.000)$ & $(.002)$ & \\
\hline $2,4,6$ & -3.853 & .625 & $(.000)$ \\
& $(.000)$ & $(.000)$ & \\
\hline
\end{tabular}

Table 3: Non-parametric tests.

To assess the magnitude of the effect for practical purposes, I in addition compute two standardized measures of effect size: Cohen's d and odds ratio, again, using the averages of the binary transfer variable over periods 1,3 , and 5 and 2,4, and 6 . The results for the full sample and for the male and female subsamples are reported in Table 4 below.

\begin{tabular}{|c|c|c|c|c|c|c|c|c|c|}
\hline \multirow[b]{2}{*}{ Periods } & \multirow[b]{2}{*}{ Sample } & \multicolumn{3}{|c|}{ B } & \multicolumn{3}{|c|}{$\mathrm{BH}$} & \multicolumn{2}{|c|}{ effect size } \\
\hline & & $\mathrm{N}$ & mean & std.dev. & $\mathrm{N}$ & mean & std.dev. & odds ratio & Cohen's d \\
\hline \multirow{3}{*}{$1,3,5$} & full & 24 & .528 & .4495 & 24 & .944 & .2123 & 1.788 & 1.1827 \\
\hline & male & 18 & .519 & .4461 & 19 & .930 & .2378 & 1.792 & 1.150 \\
\hline & female & 6 & .556 & .5018 & 5 & 1 & 0 & 1.799 & 1.251 \\
\hline \multirow[t]{3}{*}{$2,4,6$} & full & 24 & .222 & .3764 & 24 & .681 & .3330 & 3.068 & 1.2924 \\
\hline & male & 18 & 296 & .4105 & 19 & .719 & .3194 & 2.429 & 1.150 \\
\hline & female & 6 & 0 & 0 & 5 & .533 & .3801 & $\mathrm{NA}^{35}$ & 1.983 \\
\hline
\end{tabular}

Table 4: Effect-size indices.

Cohen (1998) defines effect sizes of $d=0.2$ as small, $d=0.5$ as medium, and $d=0.8$ as large. For the full sample, as well as for the male and female subsamples, the results suggest a large effect - the transfer rates in the $\mathrm{BH}$ treatment are considerably higher than in the B treatment for both male and female subsamples.

Altogether, both statistical tests and effect-size measures suggest that there are significant differences between the first-stage choices in the $\mathrm{BH}$ and $\mathrm{B}$ treatments. In the next step I perform a further analysis in which I control for gender and for other subject characteristics.

\footnotetext{
${ }^{32}$ Ranksum stands for the two-sample Wilcoxon rank-sum (or Mann-Whitney) test. I report the normalized $\mathrm{z}$ statistic and corresponding p-value below.

${ }^{33}$ Ksmirnov stands for the Kolmogorov-Smirnov test. I report the statistic and below the corresponding p-value from testing the hypothesis that average transfer is lower in the B treatment.

${ }^{34}$ Fisher stands for Fisher's exact test. I report the resulting p-value.

${ }^{35} \mathrm{~A}$ division-by-zero problem occurs, due to no variation in this subsample.
} 


\subsubsection{Econometric analysis}

During the experiment I distributed several questionnaires in order to collect basic demographic data. Specifically, I have information about subjects' age, gender, university and field of study. ${ }^{36}$ I also measured each subject's risk aversion.

The dependent variable was defined as a 0/1 dummy variable translog identifying Pay being chosen (value of 1) or not (value of 0) in a particular period. I estimate a clustered linear probability model. I prefer a linear probability model to other non-linear alternatives, as it does not rely on very specific distributional assumptions, the violation of which leads to inconsistent estimates if non-linear models are employed. Another advantage of the linear probability model lies in the straightforward interpretation of the estimated coefficients. I run clustered robust estimation to correct standard errors for likely within-subject correlation and for heteroskedasticity.

In the appendix, I provide a discussion of the robustness checks I conducted in addition to the clustered regressions analysis. As the theoretical prediction differs for low- and high-endowment periods, ${ }^{37}$ these two groups were analyzed separately.

\footnotetext{
${ }^{36}$ In addition, I collected data on: size of subject's household, number of cars in the household, and whether the subject himself has his own car and what is its approximate value, all of which serve as proxies for income. I also asked the subjects whether they considered themselves as technical types compared to their peers. I recorded the occurrence of any inconsistencies in the after-instructions questionnaire, which served as a simple test of understanding of the basic structure of the game, and in the risk-aversion questionnaire. At the end of the session I asked my subjects whether they understood the experiment. Finally, I recorded some general information about each session - the time of day it started and any session irregularities if they occurred. After running some preliminary regressions I, however, conclude that none of these variables is significant for explaining subjects' decisions. The demographic and the risk-aversion questionnaires are based on Rydval (2007).

${ }^{37}$ Recall that in periods 1,3 , and 5 the endowment was low and in periods 2,4 , and 6 the endowment was high.
} 
I start with a basic minimal model: $:^{38}$

$$
P(\text { translog }=1 \mid x)=\beta_{0}+\beta_{1} \cdot \text { age }+\beta_{2} \cdot \text { male }+\beta_{3} \cdot \text { econ }+\beta_{4} \cdot \text { BHtreat },
$$

where age corresponds to subject's reported age, male is a dummy variable defined based on subject's reported gender, and econ is a dummy variable identifying a subject having (value of 1) or not having (value of 0 ) an economic background, which is defined based on the subject's reported field of study. As I am mainly interested in the treatment effect, I also include a BH-treatment dummy BHtreat in the model.

The results from the estimation are summarized in Table 5.

\begin{tabular}{|l|l|l|}
\hline & periods 1,3,5 & periods 2,4,6 \\
\hline age & -.0761 & -.0452 \\
& $(.001)$ & $(.053)$ \\
\hline male & .0335 & .3008 \\
& $(.785)$ & $(.007)$ \\
\hline econ & -.1990 & -.0773 \\
& $(.056)$ & $(.498)$ \\
\hline BHtreat & .3019 & .3972 \\
& $(.007)$ & $(.001)$ \\
\hline mean $\widehat{p}(\mathrm{y}=1)$ & .7361 & .4514 \\
\hline \# of obs. & 144 & 144 \\
\hline joint $\mathrm{p}$-value & $(.000)$ & $(.000)$ \\
\hline
\end{tabular}

Table 5: The results from the estimation of the linear probability model. The first row of each cell reports the estimated coefficients. The second row reports the corresponding p-value. Mean $\widehat{p}(y=1)$ denotes the mean predicted probability of a transfer being made.

The model is strongly significant for both low- and high-endowment periods. Importantly, also the treatment dummy is significant at any conventional significance level.

\footnotetext{
${ }^{38}$ The second approach I used was $P($ translog $=1 \mid x)=\beta_{0}+\beta_{1} \cdot$ ra_score, where ra_score is a risk aversion score computed based on data from the risk-aversion questionnaire. Preliminary analysis suggests that age, male and econ predict ra_score well (all three are jointly significant at the $5 \%$ level, age and male with a negative sign on the coefficient, age with a positive; my proxy for income appeared insignificant, which is reasonable given my population sample). It was natural to consider these two sets of independent variables - one including ra_score only, and the other including male, age and income - as candidates for minimal models for my analysis. However, in $P($ translog $=1 \mid x)=\beta_{0}+\beta_{1} \cdot$ ra_score ra_score never appeared significant and only rarely I observed the joint significance of the estimated models. Therefore, I omit a discussion of these results.
} 
The mean predicted probability of transfer in the low-endowment periods is .7361 for the pooled sample. For the B treatment it is .5278 , for the BH treatment .9444. In the high-endowment periods, the mean predicted probability of transfer is considerably lower. For the pooled sample it is .4514, for the B treatment .2222, and for the BH treatment .6806. Thus, as I expected, the transfer rate is much higher in the high-incentive treatment. For both treatments the transfer rate is higher in low- than in high-endowment periods. This result contradicts the theoretical prediction $^{39}$ (we find the same result in the context treatment, see Krajčová \& Ortmann 2008).

Age is significant at the $5 \%$ level for low-endowment periods and at the $10 \%$ level for high-endowment periods, in both cases with a negative sign on the coefficient. An additional year of age reduces the probability of transfer by .08 with low and by .05 with high endowment.

The male dummy is not significant for low-endowment periods, but I get strong significance for high-endowment periods. ${ }^{40}$ In both cases, the sign on the coefficient is positive, meaning that men are more likely to transfer - by .03 when the endowment is low and by .30 when it is high - than women.

Econ is significant at the $10 \%$ level for low endowment and not significant for high endowment periods. The sign on the coefficient is, in both cases, negative. Thus, subjects with an economic background are less likely to transfer.

The BHtreat dummy is significant at the $1 \%$ level for both low- and highendowment periods. The sign on the coefficient is positive meaning that, as I

\footnotetext{
${ }^{39}$ Recall that in the equilibrium Participant $\mathrm{X}$ always transfers with a high endowment and never transfers with a low.

${ }^{40}$ I find no evidence of gender-specific effects such as in Krajčová \& Ortmann (2008). In the first stage, both male and female participants transfer more in the $\mathrm{BH}$ treatment than in the $\mathrm{B}$ treatment. I find some differences in the behavior of men and women - in the second stage with high endowment; and for sequential choices in the $E_{2}$ node with both low and high endowment. In all three cases, however, the size of the female subsample is too small to make any plausible inferences.
} 
expected, subjects in the high-incentive treatment are more likely to transfer - by .30 with low and by .40 with high endowment - than subjects in the benchmark treatment.

In general, the main results that can be observed from the descriptive data are also statistically significant.

\section{Discussion}

I expected that subjects in my experiment might not behave in complete accordance with the theoretical predictions made under the assumption of rationality and riskneutrality. Apart from risk attitudes, phenomena such as altruism, reciprocity (positive or negative) and/or trust might play important roles. In fact, in my data I observe considerable deviations from equilibrium at some stages of the game. The change in parameterization shifts some of the results closer and some further away from the predictions. In this section, I discuss the results, and provide some explanations for these deviations and for the observed treatment effect. I also derive implications for experimental design and the implementation of the experimental testing of leniency programs.

In the first stage, for both treatments, I observe higher transfer rates in lowthan in high-endowment periods, which contradicts the theoretical prediction. ${ }^{41}$ In the $\mathrm{BH}$ treatment the fraction of out-of-equilibrium choices is even higher than in the B treatment. A similar result is found for the context treatment in Krajčová \& Ortmann (2008).

I note that the theoretical prediction is computed under the assumption of risk

\footnotetext{
${ }^{41}$ Recall that in the equilibrium Participant $\mathrm{X}$ always transfers with a high endowment and never transfers with a low. Or, in other words, given the leniency program currently in force, theoretically, with a low endowment (thus, a low bribe) an occasional illegal transaction is not implementable.
} 
neutrality, which, as also suggested by the data from the risk-aversion questionnaire, is not likely to hold in my sample. My subjects appear to be modestly risk-averse, in accordance with the typical finding in the experimental literature (e.g. Holt \& Laury 2002, Harrison, Johnson, McInnes \& Rutström 2005). When I computed the theoretical prediction for a (modestly) risk averse subject, I found that under some (reasonable) assumptions, my chosen parameterization can lead to a no-corruption equilibrium also for the high-endowment periods. ${ }^{42}$ That is, for risk-averse subjects, it might in fact be optimal not to transfer a high endowment.

In addition, my subjects might exhibit the "preference for inclusion" reported by Cooper \& Van Huyck (2003). The authors find that subjects presented with an extensive form game are significantly more likely to make choices that allow their co-player to make a choice - and thereby to affect final payoffs - rather than choosing a terminal node. In an extensive form game this "(non)inclusion" is more salient. In my game, "inclusion" introduces a risk of significant loss. Together with risk- or loss-avoidance, it might have resulted in subjects with a "preference for inclusion" being willing to transfer and continue playing the game, but only being ready to risk the low endowment and preferring to keep the high endowment for sure.

Furthermore, note that the difference in expected payoffs to Participant Y from

\footnotetext{
${ }^{42} \mathrm{I}$ assume a standard CRRA utility function $u(x)=x^{(1-r)}$. The average risk-aversion coefficient in my sample is about 0.03 ; the maximal is about 0.1 . As the bribery game involves nodes with negative payoffs, some assumptions need to be made about the utility function in the negative domain. Prospect theory suggests that in the negative domain, the steepness of the utility function might be about twice as much as in the positive domain. For illustration, I computed the theoretical prediction for a risk-neutral subject in the $\mathrm{B}$ treatment assuming two different levels of (dis)utility from paying a 300 CZK penalty after detection: $u(-300)=-u(450)$; and $u(-300)=-u(600)$. For low endowment, the theoretical prediction is the same as for a risk-neutral subject. For high endowment it changes. For an extremely risk-averse participant $(r=0.1)$, the disutility of 450 still predicts a corruption equilibrium, however, the disutility of 600 predicts a no-corruption equilibrium. For an average risk-aversion coefficient $(r=0.03)$, the disutility of 450 is sufficient to change the theoretical prediction. I obtained analogical results for the $\mathrm{BH}$ treatment (because of a different parameterization, the relevant disutilities for the $\mathrm{BH}$ treatment are $u(-200)=-u(300)$; and $u(-200)=-u(400))$.
} 
choosing Denounce or Action a is relatively small ${ }^{43}$ in both treatments (assuming that Participant $\mathrm{X}$ will react rationally), whereas the difference in payoffs to Participant $\mathrm{X}$ is substantial. Therefore, an altruistic Participant Y might prefer choosing Action $a$ even in low-endowment periods, when this action is not maximizing the expected payoff. Or, alternatively, choosing Action a might be an act of positive reciprocity. In low-endowment periods, a rational Participant $\mathrm{X}$ might expect a rational Participant Y to choose Denounce and therefore he would not transfer. A Participant $\mathrm{X}$ who is trusting might expect Participant $\mathrm{Y}$ to choose Action $a$ in the second stage and therefore he might want to transfer.

In the $\mathrm{BH}$ treatment, the difference in expected payoffs to Participant $\mathrm{Y}$ is about the same, but the possible gain to Participant X (after Action a has been chosen) is considerably larger than in the B treatment. That is why, if the above arguments hold, the new paramererization might shift the choices even further away from the equilibrium. This is indeed what I observe in the data.

In the second stage, for both treatments, I observe about an equal split between choosing Denounce and Action a, for both low- and high-endowment periods. Nothing is almost never chosen.

Payoffs for Participant Y resulting from Nothing and Action a are the same, but taking into account the likely decisions of Participant $\mathrm{X}$ in the following stage, he is more likely to collect a higher payoff after he chooses Action $a$. This seems to be correctly recognized by the vast majority of my subjects.

As regards the relative indecisiveness of subjects between choosing Denounce or Action a, I repeat the arguments mentioned above - the difference in expected payoffs is relatively small, which together with different preferences for altruism and reciprocity might have produced these results.

\footnotetext{
${ }^{43}$ Note that this results from the nature of the game (see Figure 1).
} 
In the $E_{1}$ node, a new parameterization shifts the results closer to the prediction. Intuitively, if subjects exhibit negative reciprocity, this becomes the more salient the more there is at stake.

In the $E_{2}$ node, the majority of subjects plays equilibrium in both treatments. In the $\mathrm{BH}$ treatment the fraction of subjects who play equilibrium is slightly smaller. It is still the majority, though.

Altogether, my data to some extent confirm the main result of Buccirossi \& Spagnolo (2006) - an occasional illegal transaction is implementable when a leniency policy is in place. This becomes especially visible in the high-incentive treatment with high endowment. I observe a sensitive reaction to a parametric change that does not affect the theoretical prediction. My finding suggests that calibration, i.e. parameterization that reflects "real-life" situations reasonably well, might even be more important than in other scenarios. My data, in addition, suggest that other factors might be important as well. Trust and preferences towards others might play an important role. Further experimental testing of leniency policies might have to take these findings into account. 


\section{References}

Abbink, K., Hennig Schmidt, H., (2006). Neutral versus Loaded Instructions in a Bribery Experiment, Experimental Economics 9(2), 103-121.

Abbink, K., Irlenbusch, B., Renner, E., (2002). An Experimental Bribery Game, Journal of Law, Economics, and Organization 18(2), 428-454.

Apesteguia, J., Dufwenberg, M., Selten, R., (2007). Blowing the Whistle. Economic Theory 31, 143-166.

Bigoni, M., Fridolfsson, S.-O., Le Coq, C., Spagnolo , G., (2007). Fines, Leniency, Rewards and Organized Crime: Evidence from Antitrust Experiments. [manuscript dated November 15, 2007, not for distribution]

Bigoni, M., Fridolfsson, S.-O., Le Coq, C., Spagnolo, G., (2008). Risk Aversion, Prospect Theory, and Strategic Risk in Law Enforcement: Evidence From an Antitrust Experiment. [manuscript dated February 1, 2008, not for distribution]

Buccirossi, P., Spagnolo, G., (2006). Leniency Policies and Illegal Transactions, Journal of Public Economics 90, 1281-1297.

Cohen, J., (1988). Statistical Power for the Behavioral Sciences, $2^{\text {nd }}$ edition. Lawrence Erlbaum Associates Inc, Hillsdale.

Cooper, D., J., Van Huyck, J.,B., (2003). Evidence on the Equivalence of the Strategic and Extensive Form Representation of Games, Journal of Economic Theory 110, 290-308.

Dušek, L., Ortmann, A., Lízal, L., (2005). Understanding Corruption and Corruptibility through Experiments. Prague Economic Papers 14, 147-162. 
Fischbacher, U., (2007). Z-tree: Zurich Toolbox for Ready-made Economic Experiments - Experimenter's Manual. Experimental Economics 10(2), 171-178(8).

Gigerenzer, G., Hoffrage, U., (1995). How to Improve Bayesian Reasoning without Instruction: Frequency Formats. Psychological Review 102, 684-704.

Goeree, J., K., Holt, C., A., (2001). Ten Little Treasures of Game Theory, and Ten Intuitive Contradictions. American Economic Review 91, 1402-1422.

Gupta, S., Davoodi, H., Alonso-Terme, R., (2002). Does Corruption Affect Income Inequality and Poverty? Economics of Governance 3(1), 23-45.

Harrison, G., W., Johnson, E., McInnes, M., Rutström, E., (2005). Risk Aversion and Incentive Effects: Comment. American Economic Review 95 (3), 897-901.

Hertwig, R., Ortmann, A., (2004). The Cognitive Illusions Controversy: A Methodological Debate in Disguise That Matters to Economists. in Zwick, R., Rapoport, A. (eds.), Experimental Business Research, Kluwer Academic Publishers, Boston, MA, 361- 378 .

Holt, C., A., Laury, S., K., (2002). Risk Aversion and Incentive Effects, The American Economic Review 92 (5), 1644-1655.

Hwang, J., (2002). A Note on the Relationship Between Corruption and Government Revenue. Journal of Economic Development 27(2), 161-178.

Kamecke, U., (1997). Rotations: Matching Schemes that Efficiently Preserve the Best Reply Structure of a One Shot Game, International Journal of Game Theory 26 (3), 409-417.

Krajčová, J., Ortmann, A., (2008). Testing Leniency Programs Experimentally: The 
Impact of Natural Framing, CERGE-EI Working Paper Series, forthcoming.

Mauro, P., (1995). Corruption and Growth. Quarterly Journal of Economics, 110, 681-712.

Ortmann, A., Lízal, L., (2003). Designing and Testing Incentive-compatible and Effective Anti-corruption Measures, grant proposal successfully submitted to the Grant Agency of the Czech Republic. Grant No. 402/04/0167.

Richmanová, J., (2006). In Search of Microeconomic Models of Anti-Corruption Measures - A Review, CERGE-EI Discussion Paper No. 2006-15\%.

Richmanová, J., Ortmann, A., (2008). A Generalization of the Buccirossi \& Spagnolo (2006) Model. CERGE-EI Discussion Paper No. 2008-194.

Roth, A., (2002). The Economist as Engineer: Game Theory, Experimentation, and Computation as Tools for Design Economics, Econometrica 70(4), 1341-1378.

Rydval, O., (2007). The Impact of Financial Incentives on Task Performance: The Role of Cognitive Abilities and Intrinsic Motivation, PhD dissertation, CERGE-EI.

Spagnolo, G., (2004). Divide et Impera: Optimal Leniency Programs, C.E.P.R. Discussion Paper No. 4840 .

Tanzi, V., (1998). Corruption Around the World: Causes, Consequences, Scope and Cures. IMF Working Paper 98/63.

Williamson, O., (1983). Credible Commitments: Using Hostages to Support Exchange. American Economic Review 73, 519-540. 


\section{APPENDIX 1}

\section{Comparing the data from periods before and after the switch of roles.}

In Figure 4, I present the data from the before- and after-the-switch-of-roles periods (before-switch data in the upper rows and after-switch data below) from low- and high-endowment periods of the $\underline{\mathrm{B} \text { treatment. }}$

In both cases, I observe a somewhat higher transfer rate in the second six periods. The transfer rate is higher in the low-endowment periods than in the high before and after the switch of roles. In the $B_{0}$ node, more subjects chose the safe option (with no possibility of loss) after the switch of roles. In the $E_{2}$ node, results from before- and after-switch data are very similar, which is not the case of the $E_{1}$ node, where the relative percentages shifted closer to the equilibrium prediction.

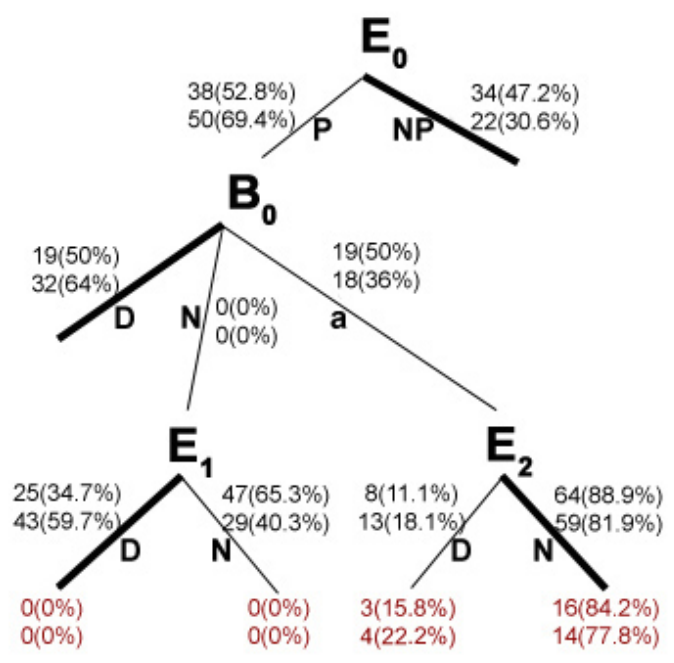

Low-endowment periods

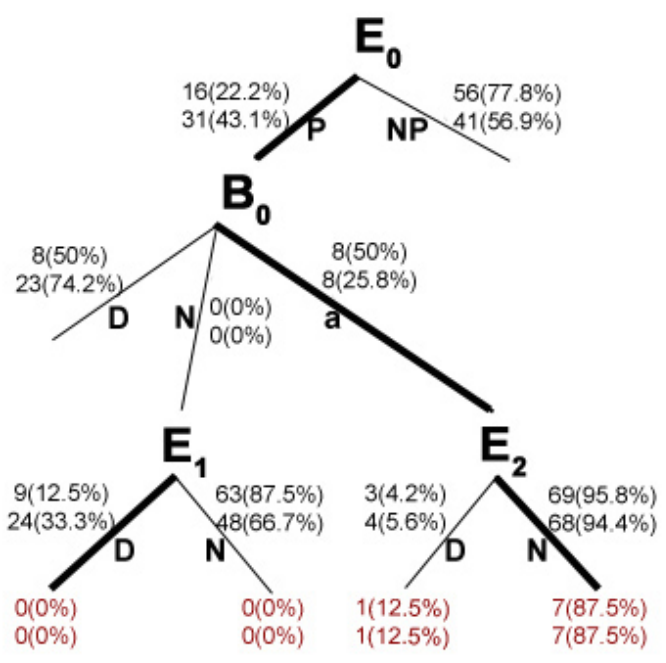

High-endowment periods

Figure 4: Before- vs. after-the-switch-of-roles data in the B treatment. Before-switch data are in the upper rows and after-switch data are below.

In Figure 5, I present the data from before- and after-switch-of-roles periods (before-switch data in the upper row and after-switch data below) from low- and high-endowment periods of the $\underline{\mathrm{BH}}$ treatment. 


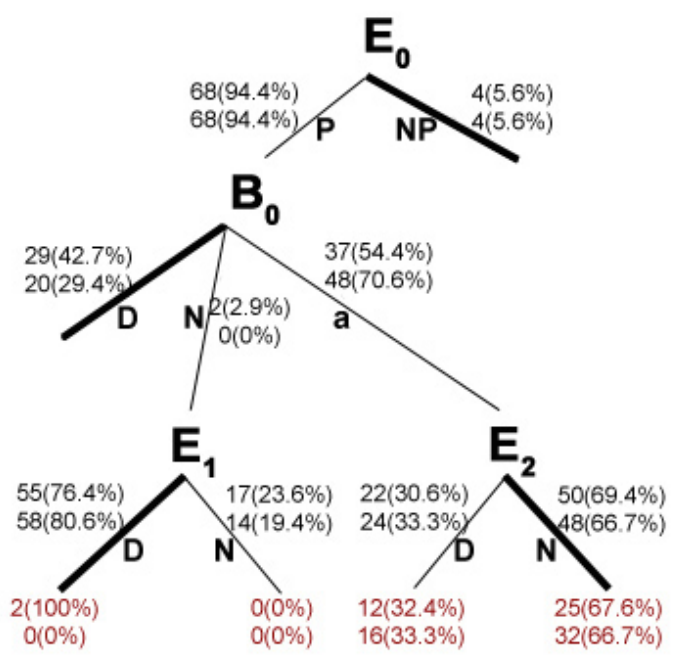

Low-endowment periods

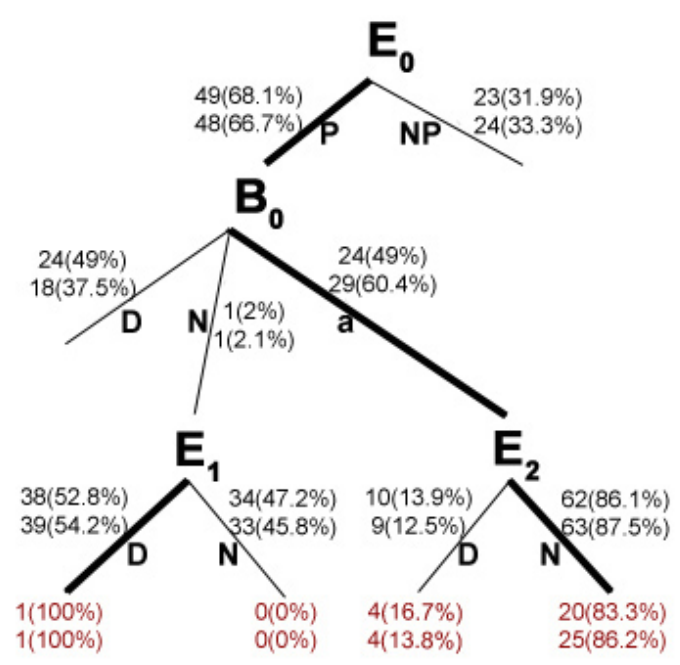

High-endowment periods

Figure 5: Before- vs. after-the-switch-of-roles data in the BH treatment. Before-switch data are in the upper rows and after-switch data are below.

In both cases, I observe no differences in the transfer rates after the switch of roles. Similarly as in the first part, the transfer rate is higher in the low-endowment periods than in the high after roles are switched. In the $B_{0}$ node, less subjects chose the safe option (with no possibility of loss) after the switch of roles in both lowand high-endowment periods. In the $E_{1}$ and $E_{2}$ nodes, results form before- and after-switch data are very similar. This is somewhat different evidence than that from the B treatment. 


\section{APPENDIX 2}

\section{Robustness checks}

I performed two types of robustness check of my estimation results. The first regards the way I treated individual observations over rounds when running regressions - this is discussed in the subsection Handling of the data. The second regards the experimental design - I run several sessions of alternative treatments in which I introduce only minor changes that do not appear to significantly affect behavior of subjects - this is discussed in the subsection Pooling the sessions.

\section{A. Handling of the data}

Throughout the analysis I have defined three alternative dependent variables, each of which captures slightly different information about the first-stage data.

Translog is a $0 / 1$ dummy variable identifying transfer being made (value of 1 ) or not (value of 0) in a particular period.

Atranslog is the average value of translog for one individual over periods 1,3, and 5 (low-endowment periods) or 2, 4 , and 6 (high-endowment periods).

Ltranslog defines the dominant choice of a subject in periods 1,3, and 5 or 2,4, and 6. For a subject who has chosen Pay two or three times out of a total three periods of interest, the dominant choice is 1; for a subject who has chosen Not Pay two or three times out of total three periods of interest, the dominant choice is 0 .

Then, using one of the three types of dependent variable, I conducted four different types of regression analysis.

Clustered regressions - as discussed in the main text, I run a clustered (robust) ${ }^{44}$ linear probability model estimation with the binary variable translog as a dependent variable.

\footnotetext{
${ }^{44}$ Standard errors are corrected for heteroskedasticity and for within-subject correlation.
} 
Regressions on Averaged data - in this case, I run an ordinary least squares estimation of atranslog. I analyze only averaged data, where higher values of atranslog correspond to more transfers being made and thus to a stronger preference for this choice. $^{45}$

Regressions on the $1^{\text {st }}$ or $2^{\text {nd }}$ period data - I estimate LPM only on the $1^{\text {st }}$ and $2^{\text {nd }}$ period translog (for low- and high-endowment periods, respectively). In this approach I am omitting part of the information, however I only use the part of the data that is not affected by the experience from previous rounds. ${ }^{46}$

Regressions on Dominant Choice - I estimate LPM using ltranslog as a dependent variable. Thus in this case, I am only looking at the dominant choice of each subject.

First I look at effect size measures, whether they give robust results for all four approaches to the data. The results are summarized in Table 6 below.

\begin{tabular}{|c|l|l|l|l|l|l|l|}
\hline \multirow{2}{*}{} & \multirow{2}{*}{ Data } & B & BH & \multicolumn{2}{c|}{ effect size } \\
\cline { 2 - 8 } & mean & std.dev. & mean & std.dev. & odds ratio & Cohen's d \\
\hline $1,3,5$ & $1^{\text {st }}$-period & .583 & .5036 & .917 & .2823 & 1.730 & .8179 \\
\cline { 2 - 7 } & average & .528 & .4495 & .944 & .2123 & 1.788 & 1.1827 \\
\cline { 2 - 7 } & dominant & .5 & .5108 & .958 & .2041 & 1.916 & 1.1772 \\
\cline { 2 - 8 } & all periods & .528 & .5027 & .944 & .2306 & 1.788 & 1.0629 \\
\hline $2,4,6$ & $2^{\text {nd }}$-period & .292 & .4643 & .708 & .4643 & 2.425 & 1.1118 \\
\cline { 2 - 7 } & average & .222 & .3764 & .681 & .3330 & 3.068 & 1.2924 \\
\cline { 2 - 7 } & dominant & .25 & .4423 & .708 & .4643 & 2.832 & 1.0107 \\
\cline { 2 - 7 } & all periods & .222 & .4187 & .681 & .4695 & 3.068 & 1.0309 \\
\hline
\end{tabular}

Table 6: Effect-size indices.

In all cases, the effects are large (recall that Cohen 1998 defines effect sizes of $d=0.8$ as large). The directions of the effects are the same in all cases - transferring is higher in the high-incentive $(\mathrm{BH})$ treatment.

Tables 7 and 8 below summarize the main results from the estimation for low-

\footnotetext{
${ }^{45}$ I also run poisson regressions on a count variable (counting the number of transfers made by an individual in the relevant three periods). The qualitative results are the same as with OLS and atranslog.

${ }^{46}$ I realize that for $2^{\text {nd }}$ period data this may not be completely true if subjects fail to realize that it is a different game they are playing in the high-endowment periods.
} 
and high-endowment periods, respectively.

\begin{tabular}{|l|l|l|l|l|}
\hline & \multicolumn{4}{|c|}{ Periods $\mathbf{1 , 3 , 5}$} \\
\hline & clustered & averaged & $1^{\text {st }}$-period & dominant \\
\hline age & -.0761 & -.0761 & -.0751 & -.0720 \\
& $(.001)$ & $(.002)$ & $(.023)$ & $(.006)$ \\
\hline male & .0335 & .0335 &. $\mathbf{1 0 2 4}$ &. $\mathbf{0 5 2 6}$ \\
& $(.785)$ & $(.791)$ & $(.465)$ & $(706)$ \\
\hline econ & -.1990 & -.1990 & -.1349 & -.2221 \\
& $(.056)$ & $(.064)$ & $(.298)$ & $(.079)$ \\
\hline BHtreat &. $\mathbf{3 0 1 9}$ & $\mathbf{. 3 0 1 9}$ & .2453 & .3334 \\
& $(.007)$ & $(.009)$ & $(.072)$ & $(.014)$ \\
\hline const & $\mathbf{2 . 3 4 4 5}$ & $\mathbf{2 . 3 4 4 5}$ & $\mathbf{2 . 2 7 8 8}$ & $\mathbf{2 . 2 2 8 4}$ \\
& $(.000)$ & $.000)$ & $(.004)$ & $(.001)$ \\
\hline mean $\widehat{p}(\mathrm{y}=1)$ &. $\mathbf{7 3 6 1}$ &. $\mathbf{7 3 6 1}$ &. $\mathbf{7 5}$ &. $\mathbf{7 2 9 2}$ \\
\hline \# of obs. & 144 & 48 & 48 & 48 \\
\hline joint $\mathrm{p}$-value & .000 & .000 & .006 & .000 \\
\hline
\end{tabular}

Table 7: Results from clustered regressions vs. regressions on averaged, $1^{\text {st }}$-period, and dominantchoice data from low-endowment periods.

\begin{tabular}{|l|l|l|l|l|}
\hline & \multicolumn{4}{|c|}{ Periods 2,4,6 } \\
\hline & clustered & averaged & $\begin{array}{l}2^{\text {nd }} \\
\text { period }\end{array}$ & dominant \\
\hline age & -.0452 & -.0452 & -.0454 & -.0449 \\
& $(.053)$ & $(.061)$ & $(.166)$ & $(.158)$ \\
\hline male & .3008 & .3008 &. $\mathbf{1 8 8 8}$ & .3011 \\
& $(.007)$ & $(.009)$ & $(.243)$ & $(.044)$ \\
\hline econ & -.0773 & -.0773 & -.2425 & -.0448 \\
& $(.498)$ & $(.511)$ & $(.138)$ & $(.785)$ \\
\hline BHtreat & .3972 & .3972 & .2844 & .4122 \\
& $(.001)$ & $(.002)$ & $(.083)$ & $(.015)$ \\
\hline const & $\mathbf{1 . 0 5 9 7}$ & $\mathbf{1 . 0 5 9 7}$ & $\mathbf{1 . 3 4 1 4}$ & $\mathbf{1 . 0 5 6 1}$ \\
& $(.046)$ & $(.046)$ & $(.067)$ & $(.139)$ \\
\hline mean $\widehat{p}(\mathrm{y}=1)$ & .4514 & .4514 & $\mathbf{. 5}$ & .4792 \\
\hline$\#$ of obs. & 144 & 48 & 48 & 48 \\
\hline joint $\mathrm{p}$-value & .000 & .000 & .003 & .000 \\
\hline
\end{tabular}

Table 8: Results from clustered regressions vs. regressions on averaged, $1^{\text {st }}$-period, and dominantchoice data from high-endowment periods.

Under all four approaches, the treatment effect is robust - I find the treatment dummy BHtreat significant. Except for the $1^{\text {st }}$ - and $2^{\text {nd }}$-period data, it is significant at the $5 \%$ level. The sign on the coefficient is positive in all cases and for both low- and high-endowment periods, meaning that the transfer rate is higher in the high-incentive treatment.

As regards other explanatory variables, the results for low-endowment periods are very similar to results from clustered regressions - age is significant at 5\%, male 
is not significant, and econ is significant only at the $10 \%$ level and not significant for the $1^{\text {st }}$-period data.

For high-endowment periods, the the results are not as robust. Age is significant at the $10 \%$ level for clustered and averaged data, and not significant for the $2^{\text {nd }}$ period and dominant-choice data. Male is significant at the $5 \%$ level with the exception of the $2^{\text {nd }}$-period data where it is not significant. Econ is never significant. The results suggest that there is larger variation in high-endowment data, which is more difficult to explain by the explanatory variables. I believe that a larger sample size would lead to more robust results.

As regards sizes and signs of coefficients, the results are very robust, especially for clustered, averaged and dominant choice data.

\section{B. Pooling the sessions}

In addition to the benchmark treatment $\mathrm{B}$ and to the high-incentive treatment BH, I conducted two plus two sessions of "automatic" treatments A and AI. Under both treatments, A and AI, I used the same game and same parameterization as in the B treatment. The only difference was that in automatic treatments, each subject played against a computer program, with six subjects in the role of Participant $\mathrm{X}$ and six subjects in the role of Participant Y. The computer program always played a (subgame perfect) optimal strategy. Subjects were acquainted with these facts in the instructions.

The only difference between the A and AI treatments was that in the AI subjects received, as a separate part of the instructions, a so-called Backwards Induction Tutorial, intended to explain the basic principles of using backwards induction.

Before pooling the data from different treatments I performed basic statistical tests in order to discover significant differences in the distributions of choices Fisher's Exact test and Wilcoxon rank-sum test. I find no evidence of significant 
differences in the distributions of choices between the A, AI and B treatments.

Afterwards, I performed two types of pooled analysis: 1) pooling the data from the $\mathrm{A}$ and $\mathrm{B}$ treatments vs. the $\mathrm{BH}$ treatment and 2) pooling the data from the A, AI and B treatments vs. the BH treatment. My main result, the significance of treatment dummy at $5 \%$, remains unaffected.

See Table 9 for the regression results for low- and high-endowment periods. Clearly, pooling slightly different treatments leads to noisier results, which is not very surprising. Importantly, the treatment dummy remains significant at the $5 \%$ level.

\begin{tabular}{|l|l|l|l|l|l|l|}
\hline & \multicolumn{3}{|c|}{ Periods 1,3,5 } & \multicolumn{3}{c|}{ Periods 2,4,6 } \\
\hline & $\mathrm{B}$ vs. BH & $\mathrm{B}, \mathrm{A}$ vs. BH & $\mathrm{B}, \mathrm{A}, \mathrm{Al}$ vs. BH & $\mathrm{B}$ vs. BH & $\mathrm{B}, \mathrm{A}$ vs. BH & $\mathrm{B}, \mathrm{A}, \mathrm{Al}$ vs. BH \\
\hline age & -.0761 & -.0652 & -.0376 & -.0452 & -.0229 & -.0186 \\
& $(.001)$ & $(.007)$ & $(.160)$ & $(.053)$ & $(.338)$ & $(.418)$ \\
\hline male & .0335 & -.0097 & -.0178 & .3008 &. $\mathbf{1 7 2 6}$ & .1079 \\
& $(.785)$ & $(.932)$ & $(.863)$ & $(.007)$ & $(.128)$ & $(.317)$ \\
\hline econ & -.1990 & -.2152 & -.1572 & -.0773 & -.1638 & -.1365 \\
& $(.056)$ & $(.026)$ & $. .117)$ & $(.498)$ & $(.127)$ & $(.164)$ \\
\hline BHtreat & .3019 & .2898 & .3550 & .3972 & .2949 & .2831 \\
& $(.007)$ & $(.001)$ & $(.000)$ & $(.001)$ & $(.007)$ & $(.006)$ \\
\hline const & $\mathbf{2 . 3 4 4 5}$ & $\mathbf{2 . 1 5 7 7}$ & $\mathbf{1 . 4 7 5 6}$ & $\mathbf{1 . 0 5 9 7}$ &. $\mathbf{7 9 9 4}$ & .7613 \\
& $(.000)$ & $(.000)$ & $(.016)$ & $(.046)$ & $(.133)$ & $(.130)$ \\
\hline mean $\widehat{p}(\mathrm{y}=1)$ & .7361 & .7111 & .6806 & .4514 & .4556 & .4491 \\
\hline$\#$ of obs. & 144 & 180 & 216 & 144 & 180 & 216 \\
\hline joint p-value & .000 & .000 & .000 & .000 & .000 & .002 \\
\hline
\end{tabular}

Table 9: Results from the estimation of basic vs. extended data sets. 
Individual researchers, as well as the on-line and printed versions of the CERGE-EI Working Papers (including their dissemination) were supported from the following institutional grants:

- Center of Advanced Political Economy Research [Centrum pro pokročilá politickoekonomická studia], No. LC542, (2005-2009),

- Economic Aspects of EU and EMU Entry [Ekonomické aspekty vstupu do Evropské unie a Evropské měnové unie], No. AVOZ70850503, (2005-2010);

- Economic Impact of European Integration on the Czech Republic [Ekonomické dopady evropské integrace na ČR], No. MSM0021620846, (2005-2011);

Specific research support and/or other grants the researchers/publications benefited from are acknowledged at the beginning of the Paper.

(c) Jana Krajčová, 2008

All rights reserved. No part of this publication may be reproduced, stored in a retrieval system or transmitted in any form or by any means, electronic, mechanical or photocopying, recording, or otherwise without the prior permission of the publisher.

Published by

Charles University in Prague, Center for Economic Research and Graduate Education (CERGE) and

Economics Institute ASCR, v. v. i. (EI)

CERGE-El, Politických vězňů 7, 11121 Prague 1, tel.: +420 224005 153, Czech Republic.

Printed by CERGE-EI, Prague

Subscription: CERGE-EI homepage: http://www.cerge-ei.cz

Editors: Directors of CERGE and EI

Managing editors: Deputy Directors for Research of CERGE and EI

ISSN 1211-3298

ISBN 978-80-7343-170-9 (Univerzita Karlova. Centrum pro ekonomický výzkum

a doktorské studium)

ISBN 978-80-7344-159-3 (Národohospodářský ústav AV ČR, v. v. i.) 
CERGE-EI

P.O.BOX 882

Politických vězňů 7

11121 Praha 1

Czech Republic http://www.cerge-ei.cz 